\title{
Maturation of $p$-Aminohippuric Acid Transport in the Developing Rabbit Kidney: Interrelationships of the Individual Components
}

\author{
BARBARA R. COLE, ${ }^{(29)}$ J. TREVOR BROCKLEBANK, ROBERT G. CAPPS, BRENDA N. MURRAY, \\ AND ALAN M. ROBSON \\ The Edward Mallinckrodt Department of Pediatrics, Washington University, and the Renal Division, St. Louis \\ Children's Hospital, St. Louis, Missouri, USA
}

\begin{abstract}
Summary
The excretion of both endogenous organic (aryl) acids, such as benzoic acid, and exogenous ones, such as $p$-aminohippuric acid (PAH), penicillin, and furosemide, is reduced in the human neonate and other immature animals. The unique developmental pattern of aryl acid transport in immature rabbit kidney cortex slices is produced by the interrelationships of PAH uptake, efflux, and amount of intracellular binding protein, all of which reach mature levels at different ages.

\section{Speculation}

The clinical relevance of immature mechanisms of aryl organic acid secretion by the proximal tubules of the kidney of the human infant will be recognized increasingly in the future. Increasing knowledge of the limited ability of the immature kidney to excrete exogenous organic acids such as penicillin and furosemide should aid the clinician in the management of the premature human newborn infant. In addition, it will help in understanding syndromes associated with organic acidemia syndromes that present in the young. Finally, it may well be that the cellular dysfunction of uremia will also be determined to be related in large part to the high concentrations of aryl acids produced by the kidney's inability to excrete them.
\end{abstract}

The clinical importance of mechanisms responsible for the transport of the aryl organic acids is becoming increasingly apparent. The renal transport system for these acids is responsible not only for the excretion of endogenous aryl acids but also for a wide variety of exogenous substances including the penicillins, the cephalosporins, furosemide, and ethacrynic acid $(3,23,25)$. Indeed, the observation that a wide variety of organic acids is excreted by the same transport system has been used to clinical advantage with the simultaneous administration of probenicid and penicillin, reducing the excretion of the antibiotic by competitive inhibition and thus prolonging its biologic half-life. More recently, significant elevations in the concentrations of aryl acids have been found in both the serum and cerebrospinal fluid of uremic subjects (19). This accumulation may be responsible for some of the altered proximal tubule functions that occur in uremia (8) and general organ dysfunction in uremia may result from the aryl acids' potential to act as competitive inhibitors of organic anion transport (19). Finally, abnormal urinary excretion of aryl acids, most commonly benzoic acid, has been observed in patients with mental retardation (24) and schizophrenia and other psychoses $(17,18)$, but the clinical relevance of these observations, if any, has not been defined.

A variety of studies has shown that the aryl organic acid transport system is incompletely developed in the young. In vivo the renal extraction of PAH is low in both the human neonate (4) and in immature animals (11), and in vitro studies of intracellular PAH accumulation by proximal renal tubular cells have supported the in vivo observations $(10,12)$.

Since aryl acids are excreted by the kidney in part by glomerular filtration, the decreased glomerular filtration rates in the neonate (2) will contribute to the decreased excretion of these acids. However, the principal route for excretion of these aryl acids is by active transport in the proximal renal tubule (22). This involves active transport across the basolateral membranes into the proximal tubular cell, intracellular concentration with protein binding to ligandin (13), and subsequent passive diffusion into the tubular lumen (22). Thus a reduced renal secretion of aryl acids could result from 1) immature active transport mechanisms; 2) a decrease in ligandin levels; 3 ) a decrease in the affinity of ligandin for PAH decreasing the intracellular ability to concentrate PAH; 4) a decreased diffusive capacity across the luminal membrane; 5) an increased permeability of the basolateral membranes permitting increased back leak of PAH; or 6) a combination of these changes.

The present study was undertaken to examine systematically the contribution of the individual cellular mechanisms to the reduction in aryl acid excretion in the immature rabbit kidney, PAH being used as the test aryl acid. The results indicated that the fetal kidney is unable to generate an intracellular PAH concentration gradient comparable to that seen in the mature animal due principally to a decrease in the active uptake of PAH.

Passive efflux of PAH from fetal kidney cells was decreased, helping to maintain definite, although low, intracellular accumulation of PAH. Ligandin concentrations in the immature kidneys were also decreased. Maturation of the several components of PAH accumulation occurred at different ages. The interrelationships between these maturational rates resulted in the pattern of maturation of intracellular PAH accumulation that has been described previously in the developing rabbit and rat kidneys $(9$, 12).

\section{MATERIALS AND METHODS}

\section{PAH KINETICS}

The renal tubular handling of PAH was studied by three techniques using cortical slices prepared from kidneys obtained from New Zealand White rabbits. Results from fetal animals and from those 1-10 weeks of age were compared to values obtained from young adults 6 months of age and from pregnant animals near term. The three methods of study were 1) measurement of steady state intracellular/extracellular PAH concentration ratios to evaluate ability to concentrate PAH at different ages; 2) measurement of rates of PAH uptake to determine the rate of maturation of the active transport mechanisms for the entry of organic acids into cells; and 3) measurement of rates of PAH efflux to 
indicate permeability of the cell membranes to PAH at different ages.

\section{SLICE/MEDIUM (S/M) RATIOS}

Steady state PAH concentrations were measured by methods similar to those published previously (6), and only the variations from this basic method are detailed. To obtain kidneys from fetal animals, pregnant rabbits of 29 days of gestation were killed by a blow on the head and immediately delivered by cesarean section of their fetuses which were quickly beheaded. Kidneys from these animals, from the pregnant mothers, and from all older rabbits, which were killed by a blow on the head, were removed quickly from the body, decapsulated, quartered, and placed in an iced Ringer's solution with the following composition: $\mathrm{NaCl} 131 \mathrm{mM}$, $\mathrm{KCl} 10 \mathrm{mM}, \mathrm{Na}$ acetate $10 \mathrm{mM}$, phosphate buffer $3 \mathrm{mM}, \mathrm{CaCl}_{2} 2.5$ $\mathrm{mM}, \mathrm{MgSO}_{4} 2 \mathrm{mM}$. Cortical slices of 0.3 to $0.4 \mathrm{~mm}$ thickness were then cut using a Stadie-Riggs microtome.

Slices from any individual kidney were distributed randomly among several Erlenmeyer flasks containing $4 \mathrm{ml}$ of the Ringer's solution to which were added inulin $(1300 \mathrm{mg} / \mathrm{dl})$ and PAH $(2$ $\mathrm{mg} / \mathrm{dl}$ ) so that each flask contained approximately $150 \mathrm{mg}$ tissue. In the case of the fetal animals, sufficient tissue could be obtained only by combining cortical slices from both kidneys of each rabbit in a single flask. Flasks were incubated at $27^{\circ}$ for $60 \mathrm{~min}$ in $10 \%$ oxygen using a Dubnoff shaking metabolic unit. The tissue was then removed from each flask, blotted on filter paper, weighed, and homogenized in 10\% trichloroacetic acid (TCA). Contents of the homogenizer, including washings, were filtered as was the incubation medium. Tissue and medium filtrates were analyzed for inulin using the anthrone method (27) and for PAH using the modified Bratton-Marshall reaction (21). In each experiment, at the end of incubation, tissue from representative flasks was blotted, weighed, then oven-dried at $95^{\circ}$ for $24 \mathrm{hr}$ and reweighed, the difference in weights representing total tissue water. The inulin values were used as an estimate of extracellular fluid (ECF); subtraction of this value from the value for total tissue water yielded an estimate of the intracellular fluid space (ICF). The amount of PAH calculated to be in the tissue ECF was subtracted from the total tissue PAH content to obtain intracellular PAH content. The intracellular/extracellular PAH concentration ratio was calculated by dividing intracellular PAH concentration (milligrams per dl ICF) by the concentration of PAH in the incubation medium, also expressed as milligrams per dl. For simplicity this ratio is termed the $\mathrm{S} / \mathrm{M}$ ratio. The four to eight results from any individual animal were averaged to obtain a final value for that animal.

\section{PAH UPTAKE}

Evaluation of the entry of PAH into proximal tubular cells was studied by a slight modification of the method of Foulkes and Miller (7). Slices were prepared as above and incubated for 30 min at $27^{\circ}$ in oxygenated Ringer's solution without PAH. After this preincubation period, slices weighing about $75 \mathrm{mg}$ were placed in individual flasks of oxygenated Ringer's solution containing $0.57 \mu \mathrm{M}\left[{ }^{14} \mathrm{C}\right] \mathrm{PAH}$ (spec act $11.4 \mathrm{mCi} / \mathrm{mM}$ ) and incubated at $27^{\circ}$ for periods varying from $2-30 \mathrm{~min}$. At the end of incubation, the slices were removed from each flask, blotted, and weighed. The tissue was homogenized in 10\% TCA and aliquots of each homogenate and the incubation medium were counted in a liquid scintillation counter (Packard model no. 3214) using a toluene-based scintillation fluid containing Bio-Solve (Beckman BBS-3). Representative slices from each animal were incubated to determine total tissue water and extracellular and intracellular water spaces as detailed above. Intracellular PAH was then calculated.

Intracellular $\mathrm{PAH}$, expressed per unit of tissue weight, was plotted against time of incubation. After an initial period of rapid uptake, which occurred in the first 4-6 min of incubation (Fig. 1), this plot described a straight line, the line of regression being calculated by the method of least squares. The rate reaction

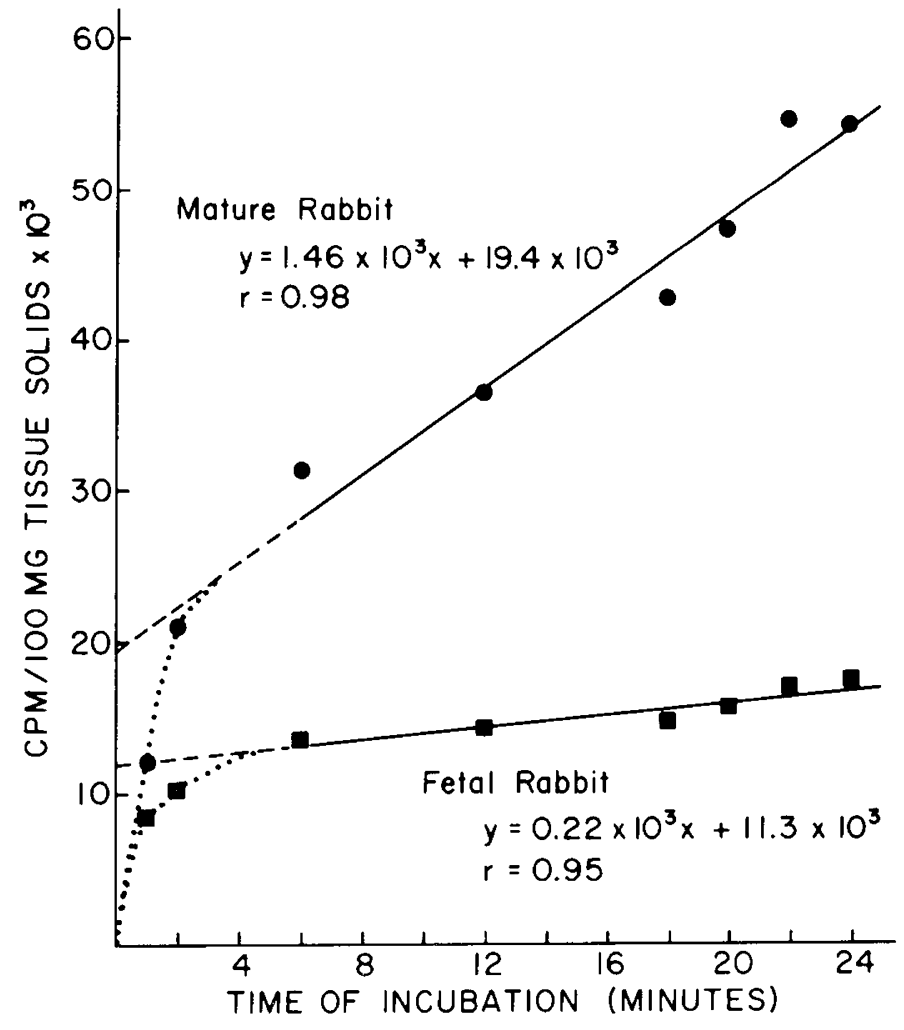

Fig. 1. Uptake of $\left[{ }^{14} \mathrm{C}\right] \mathrm{PAH}$ by renal cortical slices from a mature

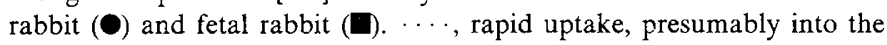
extracellular fluid space; - slower movement into the intracellular space.

constant for PAH uptake was calculated from the slope of this line using the formula of Foulkes and Miller (7).

\section{PAH RUNOUT}

Measurements of rates of efflux of PAH from cortical slices preincubated in a Ringer's solution containing $\left[{ }^{14} \mathrm{C}\right] \mathrm{PAH}$ were performed using the method of Welch and Bush (26). The only variation from this method was the measurement of efflux at 30sec intervals for the first $6 \mathrm{~min}$, and subsequently at 1 -min intervals, compared to the 1-min intervals employed by Welch and Bush.

For measurement of PAH uptake and runout all samples were counted in a liquid scintillation counter (Packard model no. 3214) using toluene-based scintillator containing Bio-Solve (Beckman BBS-3). Quenching was corrected by recounting samples after the addition of an internal standard.

\section{LIGANDIN DETERMINATIONS}

Kidneys from adult rabbits were perfused in situ for $5 \mathrm{~min}$ with saline at $4^{\circ}$, removed, decapsulated, and weighed. A $25 \%$ homogenate was prepared in a $0.25 \%$ sucrose solution in $0.01 \mathrm{M}$ phosphate buffer, pH 7.4, using the method of Kirsch et al. (13). The homogenates were centrifuged at $100,000 \times g$ for 120 min at $4^{\circ}$ in a Beckman L5-65 ultracentrifuge. The pellet and lipid layers were discarded and the protein homogenate either used immediately or stored for less than 7 days at $-20^{\circ}$. Two milliliters of the homogenate and $10 \mathrm{ml}\left[{ }^{14} \mathrm{C}\right] \mathrm{PAH}$ ( $\mathrm{spec}$ act $11.4 \mathrm{mCi} / \mathrm{mM}$ ) were made to a total volume of $4 \mathrm{ml}$ with $0.1 \mathrm{M}$ phosphate buffer and passed through a Sephadex G-100 column. The protein peaks were identified at a wavelength of $280 \mathrm{~nm}$ with a Perkin Elmer UV monitor (Coleman model no. 55). The protein content of the fractions comprising the three protein peaks was quantified (14). Two-milliliter samples from each fraction were added to a vial containing $10 \mathrm{ml}$ of a liquid scintillator (RPI 3a 70), and counted 
for ${ }^{14} \mathrm{C}$ in a liquid scintillation counter (Packard model no. 3214) using external standardization. The total protein and $\mathrm{PAH}$ content in the peak which eluted at 1.8 times the void volume (corresponding to ligandin (13)) was derived from the sum of the protein and PAH in the tubes comprising the peak. Fetal kidneys were treated in a similar fashion but could not be perfused before analysis.

\section{STATISTICAL ANALYSES}

Standard statistical methods were employed for all analyses (1); unless stated to the contrary, all values are expressed as mean \pm SEM. Values from different age groups were compared using the unpaired Student $t$-test. Differences were considered to be statistically significant only if the derived value for $p$ was $<0.05$.

\section{RESULTS}

\section{STEADY STATE PAH CONCENTRATIONS (S/M PAH RATIOS)}

The ICF space is relatively greater in fetal and newborn animals, subsequently decreasing with age (5). Since the calculated intracellular PAH levels depend on accurate determinations of inulin space, it was important to determine that the inulin space was constant during the period of incubation for all the age groups studied. Preliminary studies showed that, in slices from all ages, inulin reached its volume of distribution within $30 \mathrm{~min}$ of incubation and maintained this value for up to $120 \mathrm{~min}$.

Additional studies explored the effect of incubation time on maximum S/M PAH ratios. In the fetal and 2-week-old animals, maximum ratios were achieved at $90 \mathrm{~min}$ and were $15-20 \%$ greater than those at $60 \mathrm{~min}$. Cortex from animals aged 4 weeks or older

Table 1. Steady state levels of PAH in developing kidney

\begin{tabular}{|c|c|c|c|c|}
\hline Age & $\begin{array}{l}\text { No. of } \\
\text { animals }\end{array}$ & $\begin{array}{l}\text { Intracellular/ } \\
\text { medium } \\
\text { PAH }\end{array}$ & $\begin{array}{c}\text { Total } \\
\text { tissue } \\
\text { PAH } \\
\text { (mg/kg } \\
\text { wet } \\
\text { tissue) }\end{array}$ & $\begin{array}{c}\text { Total } \\
\text { tissue } \\
\text { PAH } \\
\text { (mg/kg } \\
\text { tissue } \\
\text { solids) }\end{array}$ \\
\hline Mature & 29 & $14.4 \pm 0.8$ & $105.3 \pm 3.2$ & $457 \pm 18.1$ \\
\hline Pregnant & 15 & $15.0 \pm 1.4$ & $104.3 \pm 5.4$ & $480 \pm 30.0$ \\
\hline Fetal & 51 & $4.1 \pm 0.3^{1}$ & $49.6 \pm 2.6^{1}$ & $317 \pm 16.9^{1}$ \\
\hline 2 Week & 25 & $9.1 \pm 0.8^{1}$ & $86.5 \pm 5.5^{1}$ & $429 \pm 27.2$ \\
\hline 4 Week & 17 & $21.8 \pm 2.3^{1}$ & $130.5 \pm 8.7^{1}$ & $615 \pm 42.7$ \\
\hline 6 Week & 22 & $17.2 \pm 0.8^{1}$ & $136.8 \pm 4.9^{1}$ & $591 \pm 26.4^{1}$ \\
\hline 8 Week & 12 & $18.0 \pm 1.4^{2}$ & $112.7 \pm 4.7$ & $460 \pm 18.9$ \\
\hline 10 Week & 6 & $17.7 \pm 1.2$ & $112.3 \pm 4.6$ & $491 \pm 17.8$ \\
\hline
\end{tabular}

${ }^{1} P<0.01$ when compared to mature levels using the unpaired student t-test.

${ }^{2} P<0.05$ when compared to mature levels using the unpaired student t-test. reached maximum values at $60 \mathrm{~min}$. However, the gradients for extracellular/intracellular sodium and potassium, as well as histologic integrity, were not well maintained in slices from animals of any age incubated for $90 \mathrm{~min}$ or longer, suggesting that there was decreasing viability of tissue incubated for longer than 60 min. For this reason all comparisons were made with values from tissue incubated for $60 \mathrm{~min}$.

Since histologic studies have shown that superficial cortical nephrons appear immature in neonatal kidneys from certain species (20), additional preliminary studies were performed to determine whether the ability of superficial cortical proximal tubules had a reduced capacity to concentrate PAH intracellularly compared either to the deep cortical or to juxtamedullary nephrons. In 2-week-old rabbits, the cortical tissue was sufficiently thick to allow three slices of $0.3-0.4 \mathrm{~mm}$ thickness. Each layer of tissue from each kidney was incubated separately as described. When the S/M PAH ratios were compared from the three layers of the four rabbits studied, no statistically significant differences were seen. The ratio in the first layer was $8.5 \pm 1.23$, in the second $10.0 \pm 1.93$, and in the third $9.0 \pm 1.55$. Thus, in these 2-week-old animals, the ability of the most superficial slices to concentrate PAH was comparable to that of the deeper slices. Similarly, in four adult rabbits, S/M PAH ratios in tissue obtained from the superficial cortex were comparable to those from deep cortical tissue, the mean values being $14.5 \pm 1.89$ and $14.7 \pm 2.10$, respectively. These results justify our use of the entire cortex to obtain slices for the subsequent studies.

The S/M PAH ratios observed in animals of various ages are summarized in Table 1 . Nonpregnant and pregnant mature animals were able to generate similar ratios of $14.4 \pm 0.8$ and 15.0 \pm 1.4 , respectively. In fetal animals, although the ability to concentrate PAH was present, it was markedly reduced, the mean ratio being only $4.1 \pm 0.3$. By 2 weeks postnatally a concentration gradient of 9.1 was achieved, but by the fourth week of age the ability to concentrate PAH had increased markedly, the mean ratio of $21.8 \pm 2.3$ being even greater than that seen in the mature animals. After the fourth week of life the S/M PAH ratios fell to the mature values.

In previous studies of maturation of $\mathrm{PAH}$ transport by the kidney, tissue PAH concentrations, expressed as total tissue PAH per unit of wet tissue weight, have been used to calculate $S / M$ PAH concentration ratios (9). Since both ECF and ICF values are proportionately larger in the fetal and neonatal animals than in the mature animals (5), the reduced S/M PAH ratios observed in the younger animals might have been in part a consequence of altered levels of tissue water. To evaluate this possibility and to permit comparison of our results with those published previously, the renal cortical PAH levels observed in the present study were expressed in alternate ways, i.e., per unit of wet tissue weight and per unit of tissue solids (Table 1). It is apparent that regardless of the method used to compare the values, the same basic relationships existed. Values of PAH accumulation were reduced in the young animals, and were increased above mature values in the 4week-old animals.

Table 2. Rates of $l^{14} C J P A H$ uptake and efflux with rate reaction constants for rabbits of varying ages ${ }^{1}$

\begin{tabular}{|c|c|c|c|c|c|c|}
\hline \multirow[b]{2}{*}{ Age } & \multirow{2}{*}{$\begin{array}{c}\text { No. of } \\
\text { animals }\end{array}$} & \multicolumn{2}{|c|}{ Uptake } & \multirow{2}{*}{$\begin{array}{c}\text { No. of } \\
\text { animals }\end{array}$} & \multicolumn{2}{|c|}{ Efflux } \\
\hline & & Slope & $\mathrm{k}_{\mathrm{i}}$ & & Slope & $\mathrm{k}_{\mathrm{e}}$ \\
\hline Mature & 4 & $768.3 \pm 68.7$ & $0.57 \pm 0.07$ & 9 & $0.0365 \pm 0.0022$ & $0.0840 \pm 0.0051$ \\
\hline Fetal & 3 & $109.3 \pm 32.6^{2}$ & $0.12 \pm 0.05^{3}$ & 6 & $0.0154 \pm 0.0022^{2}$ & $0.0356 \pm 0.0051^{2}$ \\
\hline 2 Week & 4 & $369.0 \pm 51.8^{2}$ & $0.27 \pm 0.04^{3}$ & 12 & $0.0164 \pm 0.0027^{2}$ & $0.0363 \pm 0.0065^{2}$ \\
\hline 4 Week & 6 & $696.0 \pm 98.4$ & $0.63 \pm 0.06$ & 5 & $0.0243 \pm 0.0042^{3}$ & $0.0559 \pm 0.0097^{3}$ \\
\hline 6-10 Week & 7 & $912.0 \pm 165.0$ & $0.66 \pm 0.01$ & 6 & $0.0353 \pm 0.0059$ & $0.0747 \pm 0.0134$ \\
\hline
\end{tabular}

${ }^{1} \mathrm{~K}_{\mathrm{i}}$ : rate reaction cosntant for rate of influx into cells, derived according to the formula of Foulkes and Miller (7); $\mathrm{k}_{\mathrm{e}}$ : rate reaction constant for rate of efflux from cells, derived according to the formula of Welch and Bush (25); slope expressed as counts per min per $100 \mathrm{mg}$ tissue solids per min. Specific activity of the PAH was identical in all experiments.

${ }^{2} P<0.01$ values compared to those of the mature animals using the unpaired Student $t$-test.

${ }^{3} P<0.05$ values compared to those of the mature animals using the unpaired Student $t$-test. 


\section{PAH UPTAKE}

Figure 1 shows the rates of accumulation of $\left[{ }^{14} \mathrm{C}\right] \mathrm{PAH}$ in kidney cortical slices in two representative studies, one using tissue obtained from a mature animal and the second from a fetal animal. As was typical in all studies, the uptake during the first 6 min of incubation was very rapid, presumably due to equilibration of PAH in the tissue ECF (7). After 6 min, uptake was slower and the relationship between tissue PAH and time was linear. This phase of uptake represents influx of PAH into the intracellular space and its accumulation within the cells (7) so that rate of intracellular uptake of PAH can be calculated from the slope of this portion of the plot. Similarly, the rate reaction constant for PAH uptake $\left(k_{i}\right)$ can be calculated from the slope and from PAH concentrations in the incubating media.

In Figure 1 the slope of the line depicting fetal uptake is much less steep than that of the mature animal. Thus, influx of PAH into the cells of the fetal kidney was much slower than in the mature kidney and the calculated value for $\mathrm{k}_{\mathrm{i}}$ was much lower. The values for rates of PAH uptake and for reaction constants, observed in each age group, are compared in Table 2 . In fetal animals the rate of PAH uptake $(109.3 \pm 32.6 \mathrm{cpm} / 100 \mathrm{mg}$ tissue solids $/ \mathrm{min})$ and the rate reaction constant $(0.12 \pm 0.05)$ were markedly and significantly $(p<0.01)$ reduced from the values for the mature animals $(768.3 \pm 68.7$ and $0.56 \pm 0.07 \mathrm{cpm} / 100 \mathrm{mg}$ tissue solids/min, respectively). Values increased with age, reaching mature levels by 4 weeks of age. Values for 6-, 8-, and 10week-old animals were similar and these results are shown combined in the table.

\section{PAH EFFLUX}

Figure 2 compares the rate of efflux of $\left[{ }^{14} \mathrm{C}\right] \mathrm{PAH}$ from kidney slices of a representative fetal animal with that observed from a

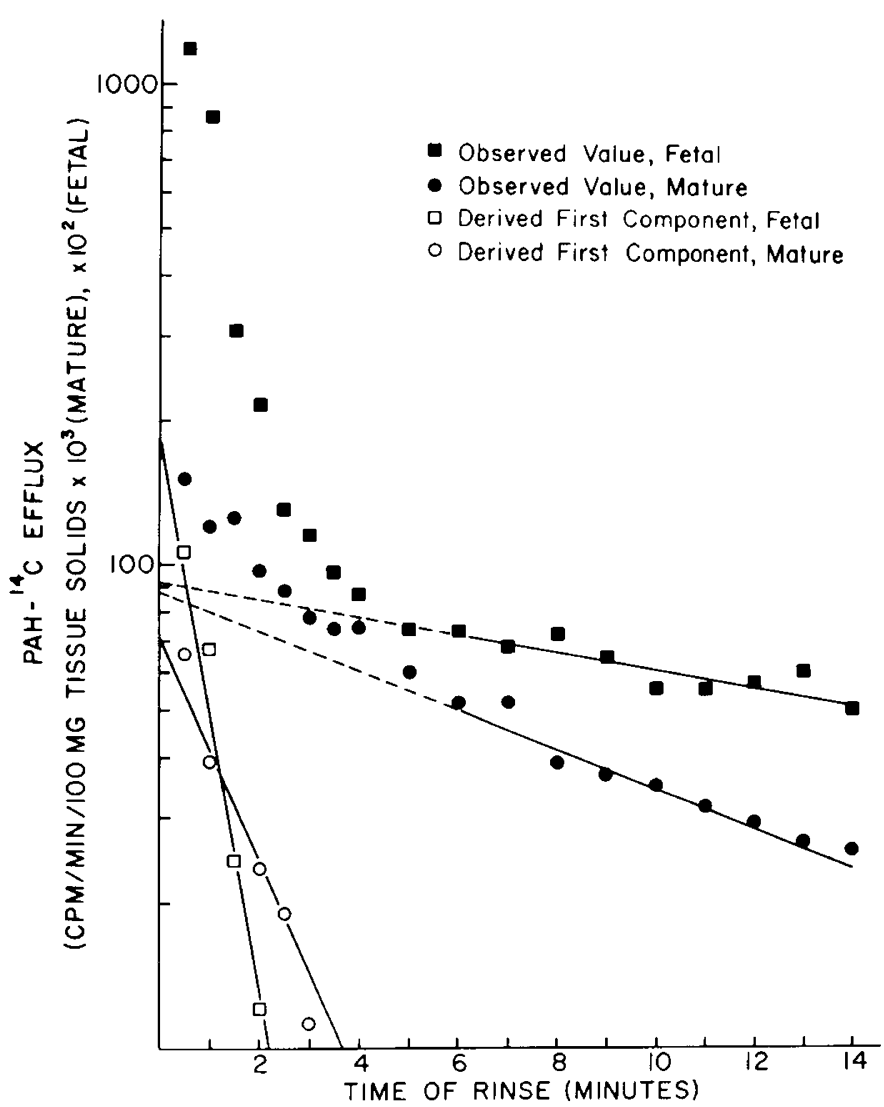

Fig. 2. Efflux of $\left[{ }^{14} \mathrm{C}\right] \mathrm{PAH}$ from cortical slices of a mature rabbit ( $\bigcirc)$ and a fetal rabbit $(\square, \square) . \bigcirc$ and $\square$, derived initial rapid efflux, presumably from the extracellular space. Note that the scale for efflux rate in the fetal animal is one-tenth that of the mature animal. typical mature animal. In both animals, after an initial rapid runout in the first 6 min, efflux plotted on a logarithmic scale against time resulted in a straight line graph. The rate reaction constants were calculated from these slopes and from the measured pool of intracellular PAH as described (26).

The values obtained from animals of different ages are shown in Table 2. The rate reaction constants for fetal and 2-week-old animals were significantly reduced from those observed in mature animals. Values in 4-week-old animals were higher but still had not reached mature values. Animals of 6, 8, and 10 weeks all had values comparable to those observed in the adult and are depicted as a group.

The slopes for efflux observed after $6 \mathrm{~min}$ were extrapolated to time zero (---, Fig. 2). These derived values for the first $6 \mathrm{~min}$ of incubation were subtracted from the observed rates of efflux, uncovering a further linear relationship (Fig. 2), which is thought to represent the initial diffusion of PAH out of the tissue ECF (26). As seen in Figure 2, the slope of this line was greater in the fetal animal study than that in the mature animal and this was observed consistently in all studies. Intermediate values were observed in the neonatal period. These differences probably represent the greater amounts of ECF (expressed per unit of kidney tissue weight) in the fetal than in the mature animals, a value which decreases progressively in postnatal life (20).

\section{LIGANDIN STUDIES}

Table 3 compares ligandin content in fetal, 4-week-old, and mature kidneys. In the fetal kidney, ligandin (expressed per g wet cortical weight) was only $37 \%$ of the mature value. Since the proportion of cortex in the fetal kidney is markedly less than in the mature, the magnitude of the decreased amount of ligandin per kidney in the fetal kidneys is even greater than that shown in Table 3 . By 4 weeks of age the ligandin content per g wet tissue weight had nearly doubled but it was still much lower than the mature value.

Since fluid occupies a greater percentage of total kidney weight in the fetal animals, the ligandin content was also expressed per mg kidney protein. A gradual increase in tissue ligandin was still observed. However, the values at different ages were not significantly different because of a wide variation in values in individual adult animals.

Although the amounts of ligandin present in kidneys obtained from animals of different ages varied, the ability of the ligandin to bind PAH in the fetal and 4-week-old kidneys was compared to that in the mature.

\section{DISCUSSION}

The present study demonstrates that the various mechanisms responsible for the generation and maintenance of intracellularextracellular PAH gradients mature at different ages. It is the interrelationship of these changes which produces the developmental pattern of S/M PAH ratios described in this and previous studies $(10,12)$. Figure 3 summarizes some of these changes in graphic form.

S/M PAH ratios in the fetal animals averaged $28 \%$ of mature levels. However, in these animals PAH uptake, in keeping with

Table 3. Ligandin content in cortical tissue from rabbits of varying ages $^{1}$

\begin{tabular}{|c|c|c|c|c|c|}
\hline \multirow[b]{2}{*}{ Age } & \multirow[b]{2}{*}{$\begin{array}{l}\text { No. } \\
\text { of } \\
\exp \end{array}$} & \multicolumn{4}{|c|}{ Ligandin content } \\
\hline & & $\begin{array}{l}\mathrm{mg} \text { ligandin } / \mathrm{mg} \\
\text { wet kidney cor- } \\
\text { tex }\end{array}$ & $P$ & $\begin{array}{c}\mathrm{mg} \text { ligandin } / \mathrm{mg} \\
\text { cortical } \\
\text { protein }\end{array}$ & $P$ \\
\hline Fetal & 3 & $4.85 \pm 1.91$ & $<0.01$ & $0.144 \pm 0.058$ & NS \\
\hline 4 weeks & 8 & $8.02 \pm 2.54$ & $<0.01$ & $0.345 \pm 0.238$ & NS \\
\hline Mature & 7 & $13.03 \pm 3.62$ & & $0.719 \pm 0.357$ & \\
\hline
\end{tabular}

${ }^{1} P$ values compare each group of immature animals with the mature. 


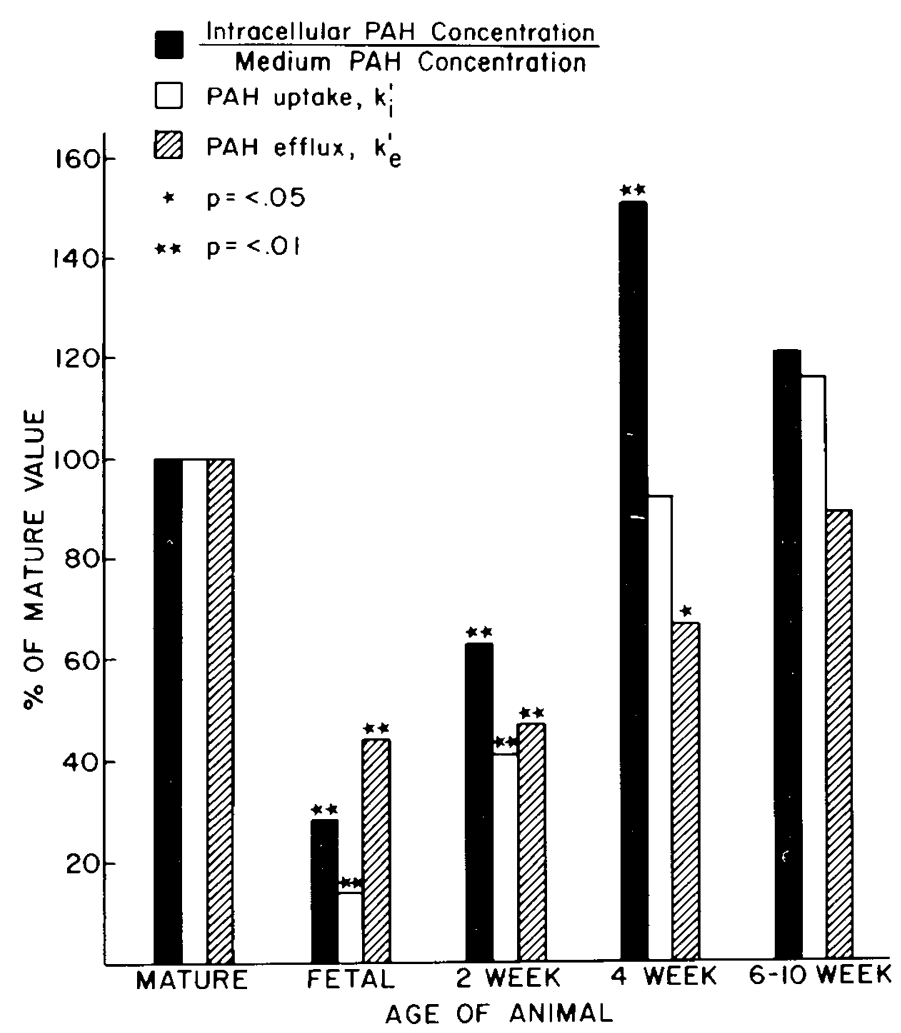

Fig. 3. Summary of PAH handling by the developing kidney.

the studies of Kim et al. (12) who postulated a decrease in active transport sites in the immature kidney, averaged only $14 \%$ of the adult value. Thus $\mathrm{S} / \mathrm{M}$ ratios in the fetal animals were approximately twice as great as might have been predicted from the uptake studies. This discrepancy can be explained by a concomitantly low passive cellular permeability to PAH in the kidneys of the fetal animals, these animals having a rate of PAH efflux that was only $43 \%$ of the mature value. This slower efflux from immature cells occurs despite the basement membranes of immature animals being thinner than those of the mature animal (15).

in the 2-week-old animals PAH uptake increased. PAH efflux remained virtually unchanged so that the ability of the cells to generate an S/M PAH gradient was increased in proportion to the increased uptake.

As found by others $(10,12)$, the 4-week animals had S/M PAH ratios that were higher than those found in mature animals. The PAH uptake and efflux studies explain this previously unexplained observation. PAH uptake had increased to mature levels but efflux was still reduced significantly to $67 \%$ of the adult levels. In the 6to 10-week-old animals rates of PAH efflux were comparable to those seen in adult animals so that their S/M PAH ratios were not significantly different from that seen in the mature animals either.

The protein ligandin, which appears to bind intracellular organic anions specifically, has been demonstrated in the proximal tubular cells and in the liver (13). The ligandin in fetal kidneys demonstrated ability to bind PAH comparable to that of the mature kidneys. However, in keeping with the observations of Kirsch et al. (13), there were decreased amounts of ligandin in the fetal kidneys. With maturation of the kidneys, ligandin content increased. The rate of this increase appeared to be greater than that of other kidney proteins (Table 3 ), but the progressive increases in ligandin content when expressed per $\mathrm{mg}$ of kidney cortex protein did not reach statistical significance. The decreased amounts of ligandin in the fetal kidneys would appear to provide a further explanation for the decreased ability of these kidneys to store PAH intracellularly, and for the low S/M PAH ratios. However, in 4-week-old animals ligandin levels were less than those in adult kidneys whereas S/M PAH ratios were higher. Thus additional studies, using more sophisticated methodology, will be required to define the role of ligandin more clearly.

Although fetal kidneys have greater total and intracellular water content than more mature kidneys, this did not account for the observed changes in S/M PAH ratios in different aged animals. When allowances were made for water content, only the magnitude of changes in intracellular PAH concentration was changed; the direction of these changes was comparable irrespective of the manner of expressing the data.

In summary, Hook and his colleagues have postulated that the reduction in accumulation of PAH by kidney slices from immature rabbits results primarily from an immaturity of or a decrease in number of functional transport sites (12). Indeed, their demonstration that PAH accumulation can be stimulated by prior treatment of animals with organic acids provides further evidence to support this hypothesis (16). Our data do not challenge these conclusions but illustrate that a multiplicity of factors are involved in the ability of cells to generate and maintain a PAH gradient. It is the relative rates of maturation of these interrelated factors and possibly other factors, as yet unidentified, which result in the pattern of development for S/M PAH ratios characterized by very low values in fetal and neonatal animals, surprisingly high levels at age 4 weeks, with a gradual fall subsequently to the adult level.

\section{REFERENCES AND NOTES}

1. Armitage, P.: Statistical Methods in Medical Research (John Wiley \& Sons, New York, 1973)

2. Barnett, H. L.: Kidney function in young infants. Pediatrics, 5: 171 (1950)

3. Bowman, R. H.: Renal secretion of $\left({ }^{35} \mathrm{~S}\right)$ furosemide and its depression by albumin binding. Amer. J. Physiol., 229: 93 (1975).

4. Calcagno, P. L., and Rubin, M. I.: Renal extraction of para-aminohippurate in infants and children. J. Clin. Invest., 42: 1632 (1963).

5. Cole, B. R., Bartlett, K. G., and Robson, A. M.: Active transport mechanisms in the maturing kidney (Abstract). Abstracts of the Vth International Congress of Nephrology, p. 133, Mexico City, October 8-13, 1972.

6. Cross, R. J., and Taggart, J. V.: Renal tubular transport: Accumulation of $p$ aminohippurate by rabbit kidney slices. Amer. J. Physiol., 161: 181 (1960)

7. Foulkes, E. C., and Miller, B. F.: Steps in p-aminohippurate transport by kidney slices. Amer. J. Physiol., 196: 86 (1959).

8. Grantham, J. J., Irwin, R. L., Qualizza, P. B., Tucker, D. R., and Whittier, F. C.: Fluid secretion in isolated proximal straight renal tubules: Effect of human uremic serum. J. Clin. Invest., 52: 2441 (1973).

9. Hirsch, G. H., and Hook, J. B.: Maturation of renal organic acid transport: Substrate stimulation by penicillin and $p$-aminohippurate (PAH). J. Pharmacol. Exp. Ther., 171: 103 (1970).

10. Hook, J. B.: Postnatal development of renal transport systems in the maturing kidney. Proceedings of the Fifth International Congress of Nephrology, Mexico, 1972, Vol. 1, p. 6 (Karger, Basel, 1974)

11. Horster, M., and Lewy, J. E.: Filtration fraction and extraction of PAH during the neonatal period in the rat. Amer. J. Physiol., 219: 1061 (1970).

12. Kim, J. K., Hirsch, G. H., and Hook, J. B.: In vitro analysis of organic ion transport in renal cortex of the newborn rat. Pediat. Res., 6: 600 (1972).

13. Kirsch, R., Fleischner, G., Kamisaka, K., and Arias, J. M.: Structural and functional studies of ligandin, a major renal organic anion-binding protein. J. Clin. Invest., 55: 1009 (1975)

14. Lowry, O. H., Rosebrough, N. J., Farr, A. L., and Randall, R. J.: Protein measurements with the Folin phenol reagent. J. Biol. Chem., 193: 265 (1951).

15. Pegg, D. G., Bernstein, J., and Hook, J. B.: Biochemical and ultrastructural correlates of substrate stimulation of renal organic anion transport. Proc. Soc. Exp. Biol. Med. 151: 720 (1976).

16. Pegg, D. G., Hewitt, W. R., and Hook, J. B.: Substrate stimulation of paminohippuric acid transport: Effect on uptake and runout. Proc. Soc. Exp. Biol. Med., 149: 546 (1975).

17. Perry, T. L., Hansen, S., Diamond, S., Melancon, S. B., and Lesk, D.: Acetic and benzoic acids in the urine of patients with chronic schizophrenia. Clin. Chim. Acta, 31: 181 (1971)

18. Perry, T. L., Hansen, S., and Lesk, D.: Benzoic aciduria in chronic psychoses. In: J. Stern and C. Toothill: Organic Acidurias, p. 99 (Churchill Livingstone, Edinburgh, 1972).

19. Porter, R. D., Cathcart-Rake, W. F., Wan, S. H., Whittier, F. C., and Grantham, J. J.: Secretory activity and aryl acid content of serum, urine, and cerebrospinal fluid in normal and uremic man. J. Lab. Clin. Med., 85: 723, (1975).

20. Rennick, B., Hamilton, B., and Evans, R.: Development of renal tubular transports of TEA and PAH in the puppy and piglet. Amer. J. Physiol., 201: 743 (1961).

21. Smith, H. W., Finkelstein, K., Alminosa, L., et al.: The renal clearances of substituted hippuric acid derivatives and other aromatic acids in dog and man. J. Clin. Invest., 24: 388 (1945).

22. Tune, B. M., Burg, M. B., and Patlak, C. S.: Characteristics of $p$-aminohippurate transport in proximal renal tubules. Amer. J. Physiol., 217: 1057 (1969). 
23. Tune, B. M., Fernholt, M., and Schwartz, A.: Mechanism of cephaloridine transport in the kidney. J. Pharmacol. Exp. Ther., 191: 311 (1974).

24. Watts, R. W. E., Chalmers, R. A., and Lawson, A. M.: Abnormal organic acidurias in mentally retarded patients. Lancet, $i$ : 368 (1975).

25. Weiner, J. M.: Transport of weak acids and bases. In: J. Orloff and R. W. Berliner: Handbook of Physiology, Section 8: Renal Physiology, Vol. 1, Chap. 17, pp. 521-554 (The Williams \& Wilkins Co., Baltimore, 1973).

26. Welch, L. T. and Bush, M. T.: Intracellular distribution and runout of $p$ aminohippurate in rabbit kidney slices. Amer. J. Physiol., 218: 1751 (1968).

27. White, R. P., and Samson, F. E.: Determination of inulin in plasma and urine by use of anthrone. J. Lab. Clin. Med., 43: 475 (1954).

28. This research was supported in part by Special Fellowship 5FO3HD 49,884 (B.R.C.), by a fellowship from the Kidney Foundation of Eastern Missouri and Metro-East (J.T.B.), by Career Development Award 5 K04 AM 70236 (A.M.R.), and by Program Project Grant AM 09976.

29. Requests for reprints should be addressed to: B. R. Cole, M.D., Department of Pediatrics, St. Louis Children's Hospital, 500 South Kingshighway, P.O. Box 14871, St. Louis, MO 63178.

30. Received for publication September 2, 1977

31. Accepted for publication December 21, 1977.

Copyright (c) 1978 International Pediatric Research Foundation, Inc 0031-3998/78/1216-0992\$02.00/0 